\section{Mechanism of the Biological Synthesis of Acetylcholine}

Stedman and Stedman have stated in a recent issue of NATURE ${ }^{1}$ that the presence of acetoacetate leads to acetylcholine synthesis in the brain. The evidence for this conclusion is apparently the fact that the rate of acetylcholine formation by brain tissue macerated in the presence of chloroform and eserine and incubated at $37^{\circ}$ is increased on the addition of sodium acetoacetate to the macerate.

Such evidence by itself seems to us quite insufficient to justify the conclusion that acetoacetate takes part directly in acetylcholine synthesis. In the first place, we have found that the rate of acetyl. choline formation by ox brain tissue, treated in the manner adopted by the Stedmans, is greater at $18^{\circ}$ (room temperature) than at $37^{\circ}$. In fact, this so-called synthesis of acetylcholine is no less at $0^{\circ}$ than at $37^{\circ}$. Acetylcholine production by chloroform-treated brain in the absence of added acetoacetate at $18^{\circ}$ is greater than that which occurs at $37^{\circ}$ in the presence of acetoacetate. At $45^{\circ}$ the apparent synthetic action of acetoacetate in the presence of whole ox brain is marked (even exceeding the 100 per cent increase claimed by the Stedmans to take place chiefly with the basal ganglia) but the greatest rate of acetylcholine formation found at this temperature in the presence of acetoacetate is less than that which occurs at room temperature in the absence of acetoacetate. At room temperature where, under the Stedmans' conditions, there is considerable formation of acetyl. choline, the addition of acetoacetate has little or no effect.

We have further found that, under conditions approximating as closely to the physiological as possible, substances such as glucose, sodium lactate and sodium pyruvate effect rates of synthesis of acetylcholine in brain tissue which are six to ten times that which take place when such substrates are not added ${ }^{2}$. Yet under these optimal conditions for acetylcholine synthesis in the brain, the addition of sodium acetoacetate has little or no effect on the synthesis.

It seems to us that the acetoacetate effect noted by the Stedmans is connected with the peculiar conditions under which their experiments are carried out. Maceration of brain tissue with chloroform in the presence of eserine, and incubation of this in the absence of buffer solutions or physiological media at $37^{\circ}$ under semi-anærobic conditions, certainly leads to free acetylcholine formation, but the mechanism of this formation requires elucidation. Until this elucidation has been obtained it seems to us rash to conclude, if a given substrate increases the rate of formation of acetylcholine, that this substance necessarily takes part in the synthesis of acetylcholine. Our own results lead us to believe that the action of chloroform on minced brain tissue is greatly to accelerate the breakdown of a complex precursor into free acetylcholine. We consider it likely that the Stedmans' results are connected not with a true synthesis of acetylcholine but with the breakdown of a precursor preformed in the brain tissue. Conceivably, under the conditions obtaining in the Stedmans' experiments, acetoacetate and other substances may affect the velocity of breakdown of the precursor.

It is difficult to compare the results of our experiments with those of Stedman and Stedman since the conditions under which they are carried out are so very different. But under our conditions, which very much more closely approach the physiological, there is as yet no evidence for the conclusion that acetoacetate is directly concerned with acetylcholine synthesis.

Our results and conclusions on the mode of synthesis of acetylcholine have already been communi. cated to the Physiological Society and will shortly be published in the Biochemical Journal.

P. J. G. MANN.

M. Tennenbaum.

J. H. QUASTEL.

Biochemical Laboratory,

Cardiff City Mental Hospital,
Whitchurch,

Cardiff.

Jan. 19.

1 Stedman and Stedman, NATcRe, 141, 39 (1938).

¿ See also Quastel, Tennenbaum and Wheatley, Biochem. J., 30, 1668 (1936).

\section{Ethnographical Museums}

THE student of ancient civilizations, who knows how much of the raw material of history is to be found in our museums, will be grateful to NATURE for the leading article in the issue of January 29 on the purpose and function of ethnographic collections.

The critics of the India Museum in South Kensing. ton, some of whom are apparently prepared to view with equanimity the dispersal of the present collec. tion, will have served a useful purpose if they have directed attention to the interesting experiment in arrangement which is being made under the present keeper, to whom a well-deserved tribute is paid in the article. Those readers of NATURE who are familiar with the report of the Museums Association on the museums of India, and who know from its contents how many collections of antiquities in India have defied arrangement and continue to defy examination by the specialist and student, will best be able to judge how much has been done for the study of Indian civilization by the authorities responsible for our own museum in London. The detailed accounts of Indian history and mythology that accompany the exhibits are a model of what such things ought to be. Indeed, the masterly sketch of the influence of classical art in India on the wall next to the exhibition of the recently acquired sculptures from Hudda in the entrance hall is one that even the specialist may ponder with profit.

The amalgamation of the Indian collections in South Kensington and in the British Museum would provide in London a permanent centre for the study of Indian history and Indian art, which would have no equal in Europe. The advocates of an Indian exhibition, as a step towards the solution of this problem, will command less support from students and scholars. It is appropriate to ask whether those enthusiasts for cultural relations who recommend a temporary Indian occupation of Burlington House, London, have carefully considered what they propose to exhibit. The Ajanta caves cannot be brought to the Royal Academy, nor the gateway of the Sanchi Stupa (a plaster copy of which towers over the staircase in South Kensington), nor, for that matter, the remains that still lie buried under the soil of India and of neighbouring countries, awaiting the spade of the archæologist. A mere exhibition of arts and crafts would involve just that divorce between art and life which, as is pointed out, is such a disservice to the 